\title{
$-14-$
}

\section{PLEISTOCENE GEOLOGY}

R. H. MacNEILI of ACADIA UNIVERSITY, Wolfville, Nova Scotia, has been intensively engaged since 1949 in Pleistocene mapping of the Nova Scotia mainland. His work with the NOVA SCOTIA RESEARCH FOUNDATION has supplanted federal survey projects in the area. During the summer of 1964 , Professor MacNeill supervised three parties in unravelling the delights of pleistocene sedimentation. His work has $y$ ielded through the years a number of published and unpublished re. ports, papers, and maps. Six papers, presented to the Valley Chapter of the NOVA SCOTIA INSTITUTE OF SCIENCE are entitled:

A Local Glacier in the Annapolis-Cornwallis Valley

Deeply Weathered Granite in Nova Scotia

Some rindings of a Geological Nature on the Islands of Mahone Bay, Nova Scotia

Preliminary Report on the Pleistocene Geology of the Bridgewater Sheet, Nova Scotia (with W. L. LEWIS)

Glacial Deposits of the Sporting Lake Stream area, Nova Scotia

Evidence of Three Pleistocene Till Sheets in the Weymouth Hills Area, Nova Scotia

As yet unpublished preliminary reports are those of the Yarmouth, Meteghan, Weymouth, Tusket, Pubnico, Comeau Hill and Church point map sheets.

WILLIAM F. TAKE of the NOVA SCOTIA MUSEUM OF SCIENCE has been actively engaged in study of pleistocene and Recent geology in the Maritime Provinces for a period of years. Two projects which are of immediate concern to him are outlined below.

Regional Deglaciation Pattern

TAKE is correlating ice front structures, and determining their relative and absolute ages. Pelative ages are determined through spatial relationships; absolute ages through relationships to dated stratigraphic sections and dated raised shorelines. Work has centered around the Minas Basin and Minas Channel, the Pictou area, and the Atlantic Coast near Halifax.

Plejstocene and Recent Paleogeography

The NOVA SCOTIA MUSEUM is supporting botanical, zoological, and archeological studies in the Maritimes, and TAKE is assisting these studies by attempting to establish the distribution of land and sea during and since the advent of the Wisconsin Ice Sheet. The Minas Basin and Minas Channel area have been studied in detail, and reconnaissance has been extended to the rulf of $S t$. Lawrence Estuary and the Atlantic Coast of Nova Scotia.

TAKE presented an abstract titled Dating the Main Wisconsin Recession in Nova. Scotia, Canada at the 1964 annual meeting of the GSA.

HAROLD $W$. BORNS of the UNIVERSITY OF MAINE is concerned with Pleistocene Ceology, and with modern glaciation as well. He is presently studying the regional framework of pleistocene glaciation in 
Maine, New Brunswick, and Nova Scotia, Specific problems include:

Late glacial sealevel change along the north

shore of the Minas Basin.

Late Pleistocene Climate in northern Nova Scotia.

Pattern of deglaciation in northern Nova Scotia.

Results of DR. BORNS' Nova Scotian work will probably be published in Science or the American Journal of Science. He presented a preliminary paper at the AAAS meeting in Montreal in December, 1964. During the coming summer, Dr. Borns plans to study an end moraine complex in eastern Maine, with hopes of dating it, and tracing it into New Brunswick.

H. L. CAMERON of ACADIA UNIVERSITY is studying in detail the pleistocene Geology of Cape Breton Island, and of some parts of mainland Nova Scotia. He is concerned with the location of ice caps, raised beaches, and moraines.

H. A. LEE of the UNIVERSITY OF NEW BRUNSWICK is writing a GSC Memoir about the deglaciation of a strip of land across the Appalachians from the Bay of Fundy at Saint John to the St. Lawrence at Rivière-du-Loup.

R. MELVIN of the UNIVERSITY OF NEV BRUNSWICK has just completed mapping 50 square miles of pleistocene sediments in the Saint John area, for an M.Sc. thesis.

P. LASALLE, graduate student at McGILL UNIVERSITY, has conducted field studies of pleistocene marine and glacial sediments in the Verchères, Berthierville, and Lac St. Jean areas of Quebec. His work was supported by the QUEBEC DEPARTMENT OF NATURAL RESOURCES.

J. $Y$. CHAGNON of the department's permanent staff will begin work on consolidated sediments of the St. Lawrence Valley in 1965. 